Supporting Information

\title{
Interference-Free Duplex Detection of Total and Active Enzyme Concentrations at a Single Working Electrode
}

Seonhwa Park, Jeonghwa Shin, Jungwook Kwon, Woohyeong Lee, Jihyeon Kim, Gyeongho Kim, Jung Min Joo, and Haesik Yang*

Department of Chemistry, Pusan National University, Busan 46241, Korea 


\section{Table of Content}

Figure S1. (a) Chronocoulograms obtained at $0.1 \mathrm{~V}$ at BSA-coated ITO electrodes after an incubation period of $30 \mathrm{~min}$ at $37{ }^{\circ} \mathrm{C}$ in tris buffer containing (i) $100 \mu \mathrm{g} / \mathrm{mL} \mathrm{GDH}, 5$ $\mathrm{mM}$ glucose, and $0.1 \mathrm{mM}$ peptide-AN, (ii) $100 \mu \mathrm{g} / \mathrm{mL} \mathrm{GDH}, 5 \mathrm{mM}$ glucose, $0.1 \mathrm{mM}$ peptide-AN and $1 \mu \mathrm{g} / \mathrm{mL}$ inactive fPSA, and (iii) $100 \mu \mathrm{g} / \mathrm{mL}$ GDH, $5 \mathrm{mM}$ glucose, 0.1 $\mathrm{mM}$ peptide-AN and $1 \mu \mathrm{g} / \mathrm{mL}$ activated fPSA. (b) Chronocoulograms obtained at $0.0 \mathrm{~V}$ at BSA-coated ITO electrodes after an incubation period of $30 \mathrm{~min}$ at $37^{\circ} \mathrm{C}$ in tris buffer containing (i) $100 \mu \mathrm{g} / \mathrm{mL}$ GDH, $5 \mathrm{mM}$ glucose, and $0.1 \mathrm{mM}$ peptide-AN and (ii) 100 $\mu \mathrm{g} / \mathrm{mL} \mathrm{GDH}, 5 \mathrm{mM}$ glucose, $0.1 \mathrm{mM}$ peptide-AN, and $100 \mathrm{ng} / \mathrm{mL}$ thermolysin.

Figure S2. Schematic representation for the procedure of the sandwich-type affinity binding performed before the chronocoulometric measurement.

Figure S3. Cyclic voltammograms (at a scan rate of $20 \mathrm{mV} / \mathrm{s}$ ) obtained at bare ITO electrodes in tris buffer containing one of $1.0 \mathrm{mM}$ (i) Fc, (ii) AN, and (iii) peptide-AN.

Figure S4. Cyclic voltammograms (at a scan rate of $20 \mathrm{mV} / \mathrm{s}$ ) obtained at bare ITO electrodes after an incubation period of $10 \mathrm{~min}$ at $25^{\circ} \mathrm{C}$ in tris buffer $(\mathrm{pH} 7.5,50 \mathrm{mM}$ tris, and $1 \mathrm{M} \mathrm{NaCl}$ ) containing (a) (i) $0.1 \mathrm{mM} \mathrm{Fc}$, (ii) $0.1 \mathrm{mM} \mathrm{Fc}, 100 \mu \mathrm{g} / \mathrm{mL} \mathrm{GDH}$, and $5 \mathrm{mM}$ glucose, (iii) $0.1 \mathrm{mM} \mathrm{Fc}, 100 \mu \mathrm{g} / \mathrm{mL} \mathrm{GOx}$, and $5 \mathrm{mM}$ glucose, (iv) $0.1 \mathrm{mM} \mathrm{Fc}, 100 \mu \mathrm{g} / \mathrm{mL}$ DI, and $2 \mathrm{mM}$ NADH, (b) (i) $0.1 \mathrm{mM} \mathrm{AN}$, (ii) $0.1 \mathrm{mM} \mathrm{AN}, 100 \mu \mathrm{g} / \mathrm{mL} \mathrm{GDH}$, and $5 \mathrm{mM}$ glucose, (iii) $0.1 \mathrm{mM} \mathrm{AN}, 100 \mu \mathrm{g} / \mathrm{mL}$ GOx, and $5 \mathrm{mM}$ glucose, and (iv) $0.1 \mathrm{mM} \mathrm{AN}, 100$ $\mu \mathrm{g} / \mathrm{mL}$ DI, and $2 \mathrm{mM}$ NADH.

Figure S5. Histograms of the charge values measured at $100 \mathrm{~s}$ in the chronocoulograms obtained at BSA-coated ITO electrodes at various applied potentials [(a) 0.1, 0.15, 0.2, 0.25 , and $0.3 \mathrm{~V}$ and (b) $0.0,0.05,0.1$, and $0.15 \mathrm{~V}$ ] in tris buffer containing (a) (i) $0.1 \mathrm{mM}$ Fc, $0.1 \mathrm{mM}$ peptide-AN, and $5 \mathrm{mM}$ glucose and (ii) $0.1 \mathrm{mM} \mathrm{Fc}, 0.1 \mathrm{mM}$ peptide-AN, 5 $\mathrm{mM}$ glucose, and $100 \mu \mathrm{g} / \mathrm{mL}$ GDH and (b) (i) $0.1 \mathrm{mM} \mathrm{Fc}, 0.1 \mathrm{mM}$ peptide-AN, $5 \mathrm{mM}$ glucose, and $100 \mu \mathrm{g} / \mathrm{mL}$ GDH and (ii) $0.1 \mathrm{mM} \mathrm{Fc}, 0.1 \mathrm{mM} \mathrm{AN}, 5 \mathrm{mM}$ glucose, and 100 $\mu \mathrm{g} / \mathrm{mL}$ GDH.

Figure S6. Chronocoulograms obtained (a) at $0.1 \mathrm{~V}$ without incubation and (b) $0.0 \mathrm{~V}$ after 30 min incubation at $37^{\circ} \mathrm{C}$ in tris buffer containing $0.1 \mathrm{mM} \mathrm{Fc}, 0.1 \mathrm{mM}$ peptide-AN, and $5 \mathrm{mM}$ glucose for the simultaneous detection of tPSA and fPSA (Scheme 1) in PBSB containing various concentrations of fPSA and zero cPSA.

Figure S7. Chronocoulograms obtained (a) at $0.1 \mathrm{~V}$ without incubation and (b) $0.0 \mathrm{~V}$ after $30 \mathrm{~min}$ incubation at $37^{\circ} \mathrm{C}$ in tris buffer containing $0.1 \mathrm{mM} \mathrm{Fc}, 0.1 \mathrm{mM}$ peptide-AN, and $5 \mathrm{mM}$ glucose for the simultaneous detection of tPSA and fPSA (Scheme 1) in PBSB containing zero fPSA and various concentrations of cPSA.

Figure S8. Chronocoulograms obtained (a) at $0.1 \mathrm{~V}$ without incubation and (b) $0.0 \mathrm{~V}$ after $30 \mathrm{~min}$ incubation at $37^{\circ} \mathrm{C}$ in tris buffer containing $0.1 \mathrm{mM} \mathrm{Fc}, 0.1 \mathrm{mM}$ peptide-AN, and $5 \mathrm{mM}$ glucose for the simultaneous detection of tPSA and fPSA (Scheme 1) in (i) PBSB and (ii) female serum containing no added tPSA and PPSA. 
Figure S9. Chronocoulograms obtained (a, c) at $0.1 \mathrm{~V}$ without incubation and (b, d) 0.0 V after $30 \mathrm{~min}$ incubation at $37^{\circ} \mathrm{C}$ in tris buffer containing $0.1 \mathrm{mM} \mathrm{Fc}, 0.1 \mathrm{mM}$ peptide$\mathrm{AN}$, and $5 \mathrm{mM}$ glucose for the simultaneous detection of tPSA and fPSA (Scheme 1) in female serum $(a, b)$ containing various concentrations of fPSA and $1 \mathrm{ng} / \mathrm{mL} \mathrm{cPSA}$ and (c, d) containing $1 \mathrm{ng} / \mathrm{mL}$ fPSA and various concentrations of cPSA.

Table S1. Comparison of the concentration of tPSA concentration, the $\%$ ratio of fPSAto-tPSA, and the biopsy needs ${ }^{23}$ measured by using the immunosensor and a commercial instrument for 20 clinical serum samples.

\section{References}



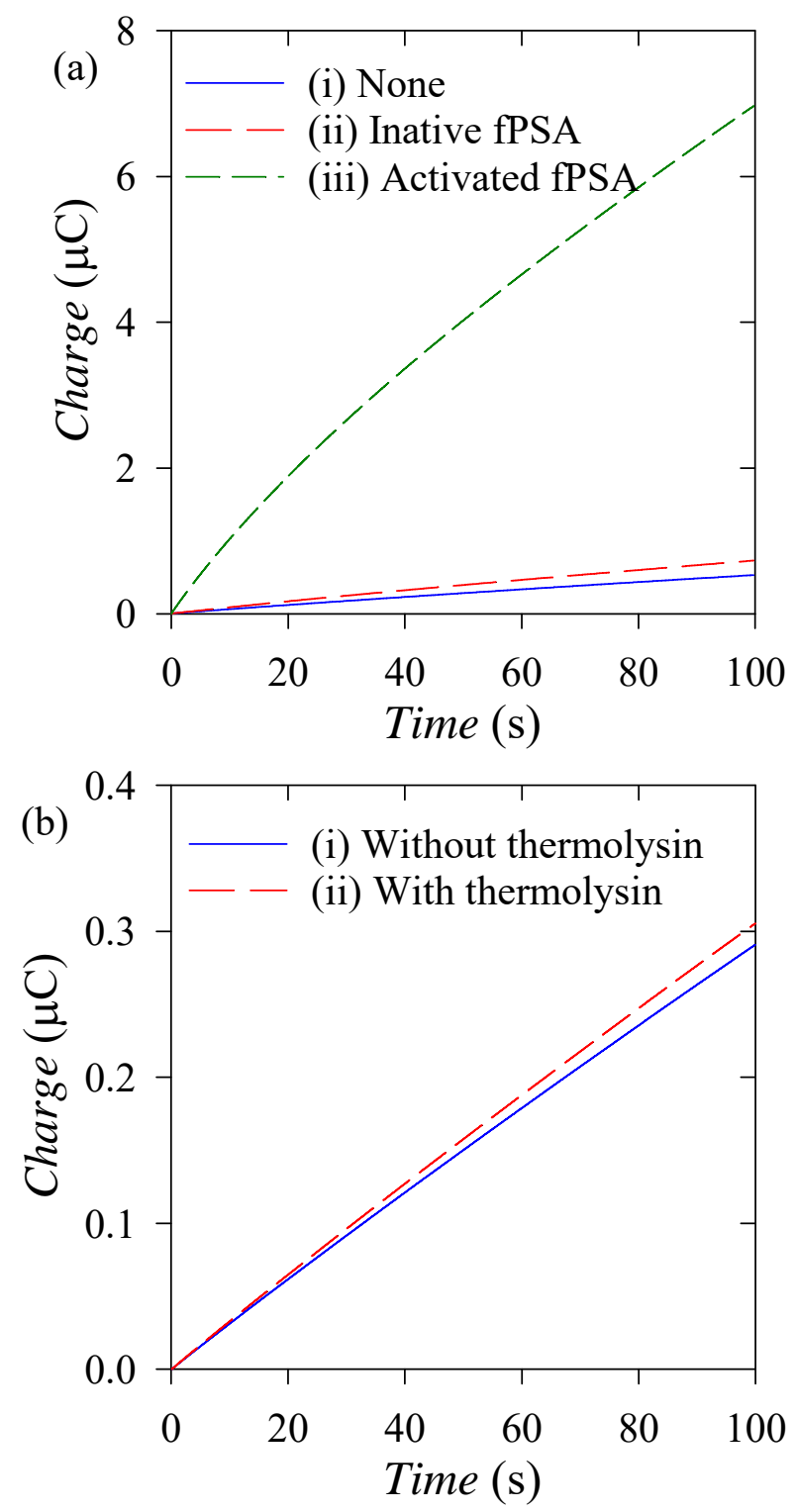

Figure S1. (a) Chronocoulograms obtained at $0.1 \mathrm{~V}$ at BSA-coated ITO electrodes after an incubation period of $30 \mathrm{~min}$ at $37{ }^{\circ} \mathrm{C}$ in tris buffer containing (i) $100 \mu \mathrm{g} / \mathrm{mL} \mathrm{GDH}, 5$ $\mathrm{mM}$ glucose, and $0.1 \mathrm{mM}$ peptide-AN, (ii) $100 \mu \mathrm{g} / \mathrm{mL} \mathrm{GDH}, 5 \mathrm{mM}$ glucose, $0.1 \mathrm{mM}$ peptide-AN and $1 \mu \mathrm{g} / \mathrm{mL}$ inactive fPSA, and (iii) $100 \mu \mathrm{g} / \mathrm{mL}$ GDH, $5 \mathrm{mM}$ glucose, 0.1 $\mathrm{mM}$ peptide-AN and $1 \mu \mathrm{g} / \mathrm{mL}$ activated fPSA. (b) Chronocoulograms obtained at $0.0 \mathrm{~V}$ at BSA-coated ITO electrodes after an incubation period of $30 \mathrm{~min}$ at $37{ }^{\circ} \mathrm{C}$ in tris buffer containing (i) $100 \mu \mathrm{g} / \mathrm{mL}$ GDH, $5 \mathrm{mM}$ glucose, and $0.1 \mathrm{mM}$ peptide-AN and (ii) 100 $\mu \mathrm{g} / \mathrm{mL}$ GDH, $5 \mathrm{mM}$ glucose, $0.1 \mathrm{mM}$ peptide-AN, and $100 \mathrm{ng} / \mathrm{mL}$ thermolysin.

To determine the optimal conditions for simultaneous detection, commercial human fPSA was used. However, the commercial fPSA was an inactive form of fPSA, which required activation by thermolysin ${ }^{\mathrm{S} 1}$ in all experiments, except in the case of the simultaneous detection in clinical serum, which contains active fPSA. Importantly, the addition of thermolysin did not influence the electrochemical signals. 


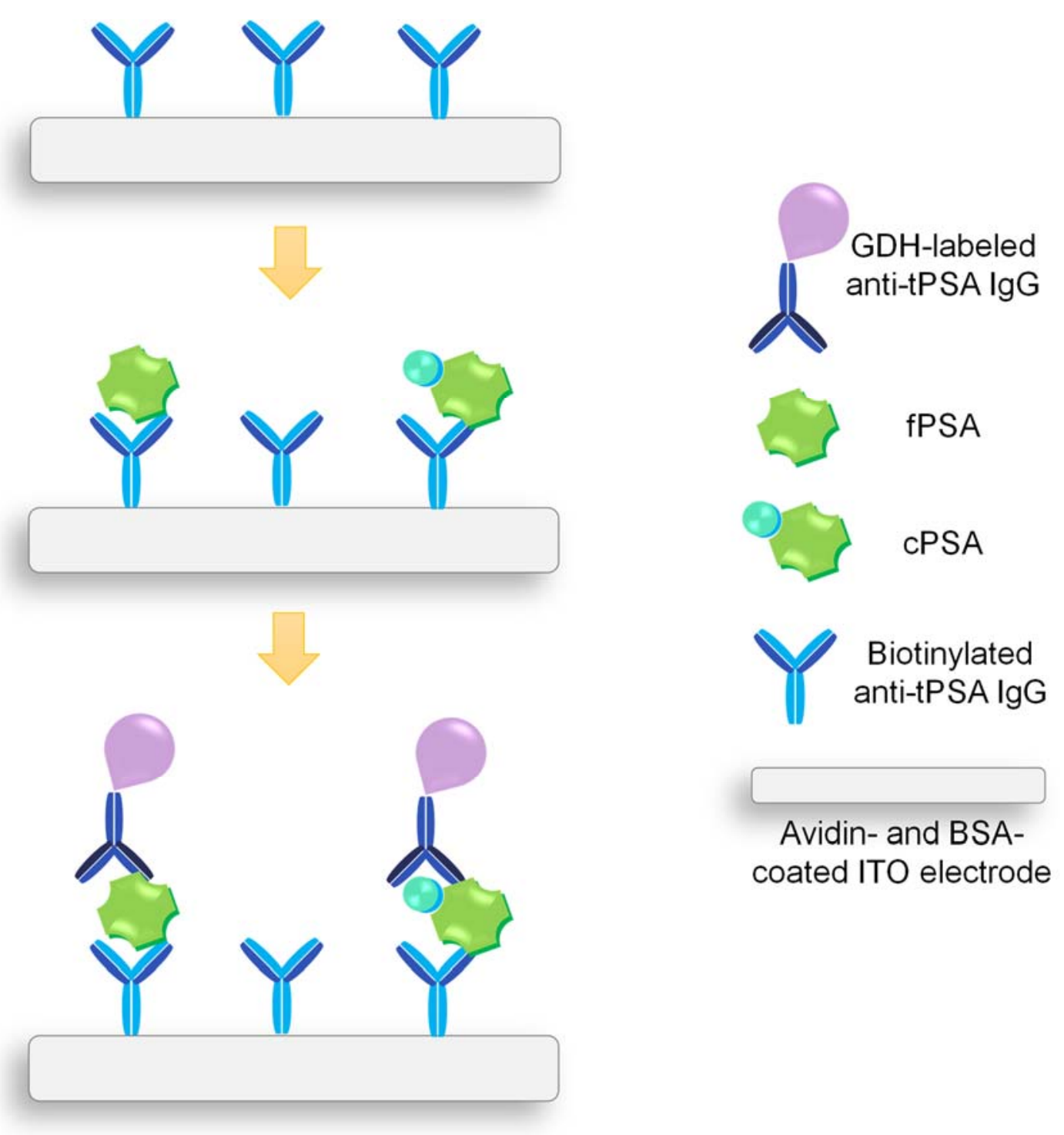

Figure S2. Schematic representation for the procedure of the sandwich-type affinity binding performed before the chronocoulometric measurement. 


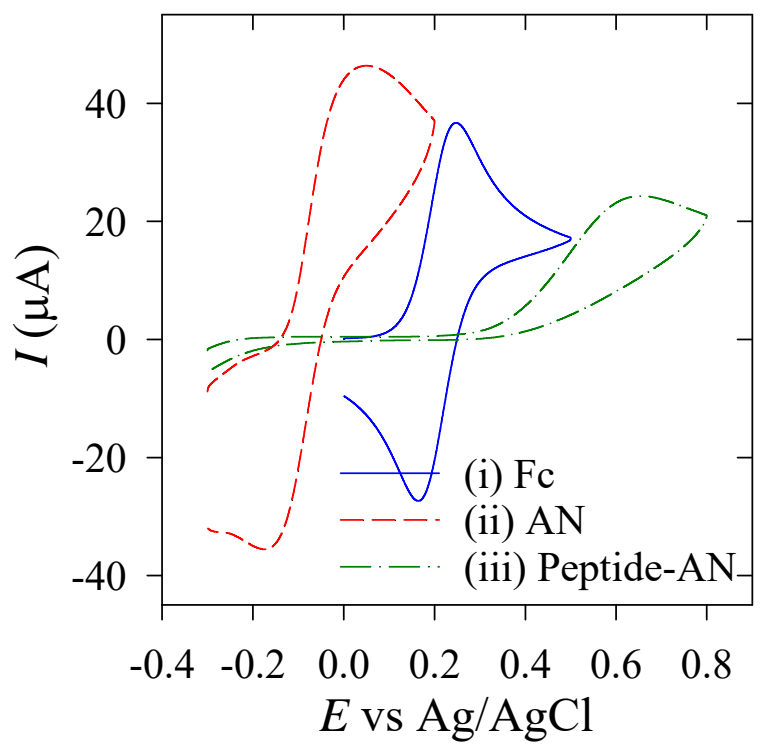

Figure S3. Cyclic voltammograms (at a scan rate of $20 \mathrm{mV} / \mathrm{s}$ ) obtained at bare ITO electrodes in tris buffer containing one of $1.0 \mathrm{mM}$ (i) Fc, (ii) AN, and (iii) peptide-AN. When peptide-AN is oxidized, it seems that an irreversible chemical reaction occurs, resulting in no reduction current down to $0.0 \mathrm{~V}$ during the cathodic scan.
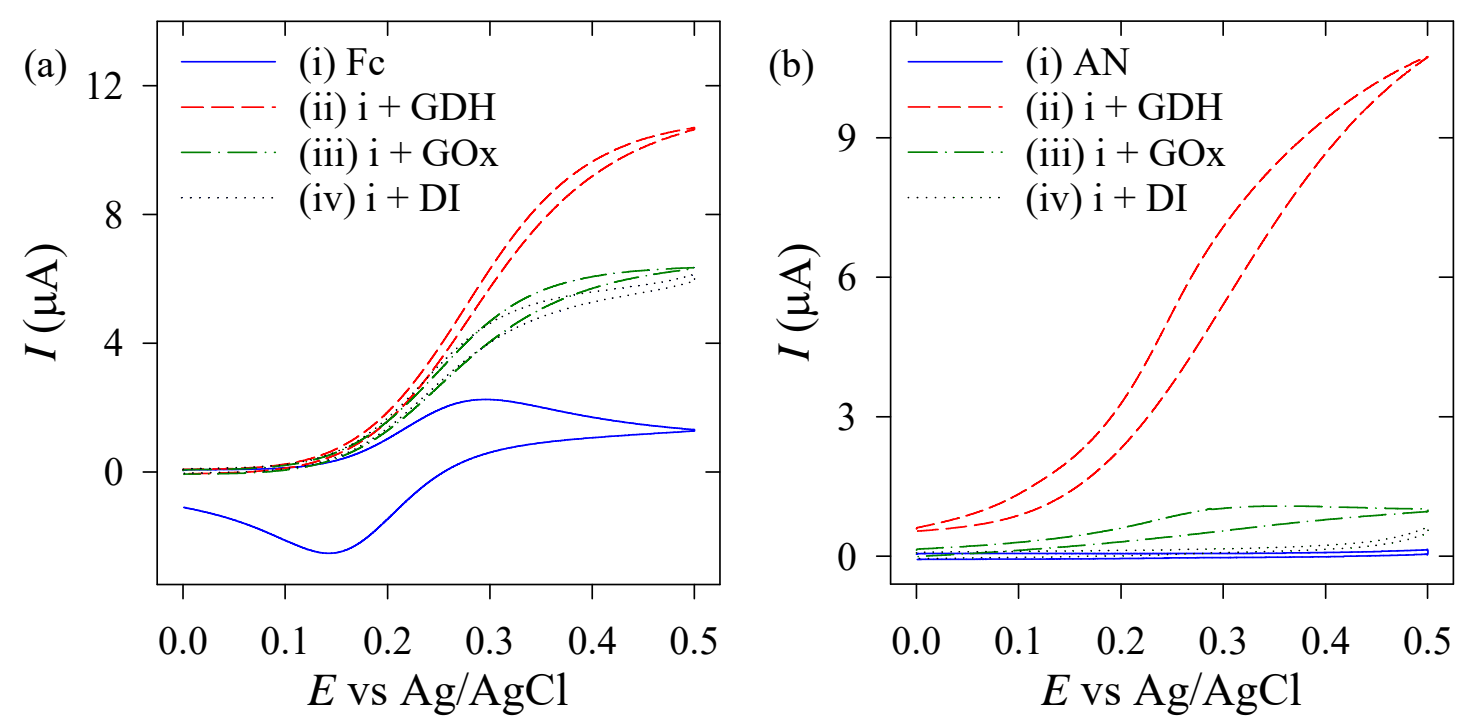

Figure S4. Cyclic voltammograms (at a scan rate of $20 \mathrm{mV} / \mathrm{s}$ ) obtained at bare ITO electrodes after an incubation period of $10 \mathrm{~min}$ at $25^{\circ} \mathrm{C}$ in tris buffer $(\mathrm{pH} 7.5,50 \mathrm{mM}$ tris, and $1 \mathrm{M} \mathrm{NaCl}$ ) containing (a) (i) $0.1 \mathrm{mM} \mathrm{Fc}$, (ii) $0.1 \mathrm{mM} \mathrm{Fc}, 100 \mu \mathrm{g} / \mathrm{mL} \mathrm{GDH}$, and $5 \mathrm{mM}$ glucose, (iii) $0.1 \mathrm{mM} \mathrm{Fc}, 100 \mu \mathrm{g} / \mathrm{mL} \mathrm{GOx}$, and $5 \mathrm{mM}$ glucose, (iv) $0.1 \mathrm{mM} \mathrm{Fc}, 100 \mu \mathrm{g} / \mathrm{mL}$ DI, and $2 \mathrm{mM} \mathrm{NADH}$, (b) (i) $0.1 \mathrm{mM} \mathrm{AN}$, (ii) $0.1 \mathrm{mM} \mathrm{AN}, 100 \mu \mathrm{g} / \mathrm{mL} \mathrm{GDH}$, and $5 \mathrm{mM}$ glucose, (iii) $0.1 \mathrm{mM} \mathrm{AN}, 100 \mu \mathrm{g} / \mathrm{mL}$ GOx, and $5 \mathrm{mM}$ glucose, and (iv) $0.1 \mathrm{mM} \mathrm{AN}, 100$ $\mu \mathrm{g} / \mathrm{mL} \mathrm{DI}$, and $2 \mathrm{mM} \mathrm{NADH}$. 

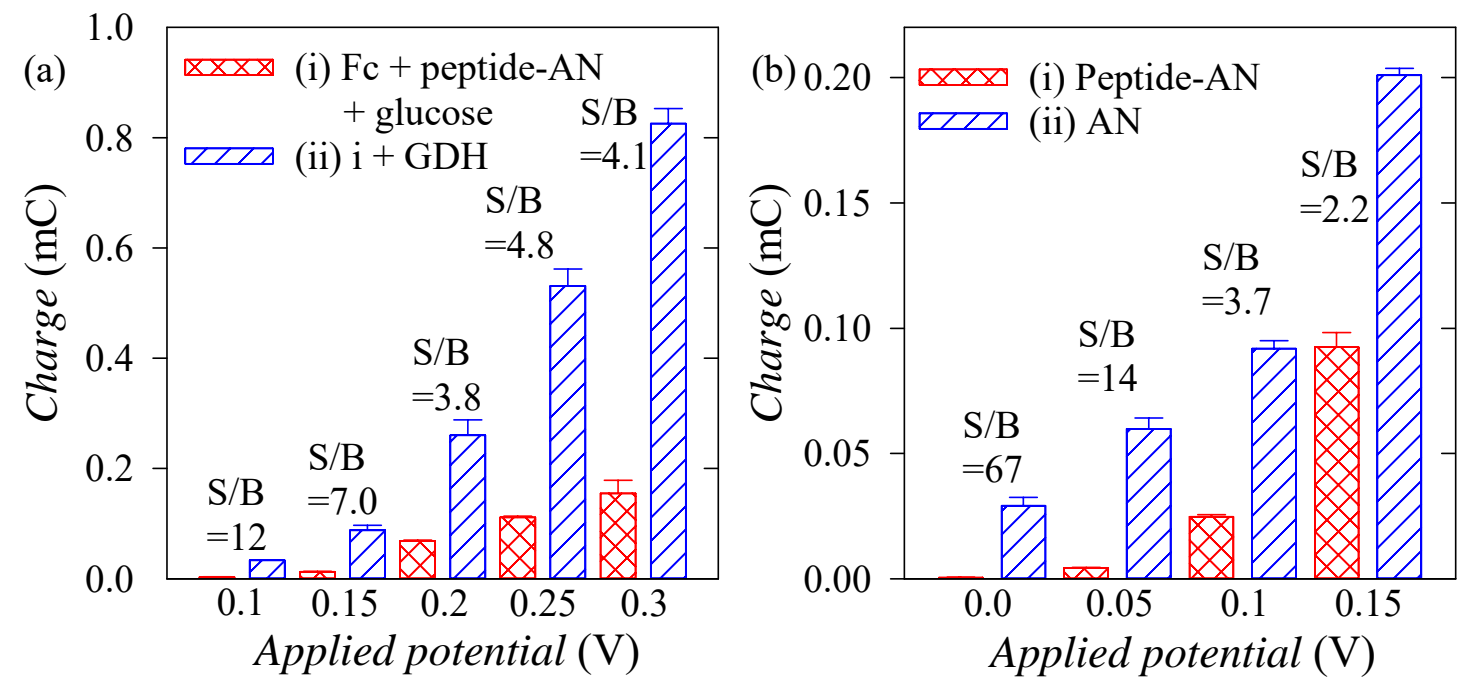

Figure S5. Histograms of the charge values measured at $100 \mathrm{~s}$ in the chronocoulograms obtained at BSA-coated ITO electrodes at various applied potentials [(a) 0.1, 0.15, 0.2, 0.25 , and $0.3 \mathrm{~V}$ and (b) $0.0,0.05,0.1$, and $0.15 \mathrm{~V}$ ] in tris buffer containing (a) (i) $0.1 \mathrm{mM}$ Fc, $0.1 \mathrm{mM}$ peptide-AN, and $5 \mathrm{mM}$ glucose and (ii) $0.1 \mathrm{mM} \mathrm{Fc}, 0.1 \mathrm{mM}$ peptide-AN, 5 $\mathrm{mM}$ glucose, and $100 \mu \mathrm{g} / \mathrm{mL}$ GDH and (b) (i) $0.1 \mathrm{mM} \mathrm{Fc}, 0.1 \mathrm{mM}$ peptide-AN, $5 \mathrm{mM}$ glucose, and $100 \mu \mathrm{g} / \mathrm{mL}$ GDH and (ii) $0.1 \mathrm{mM} \mathrm{Fc}, 0.1 \mathrm{mM} \mathrm{AN}, 5 \mathrm{mM}$ glucose, and 100 $\mu \mathrm{g} / \mathrm{mL}$ GDH. 

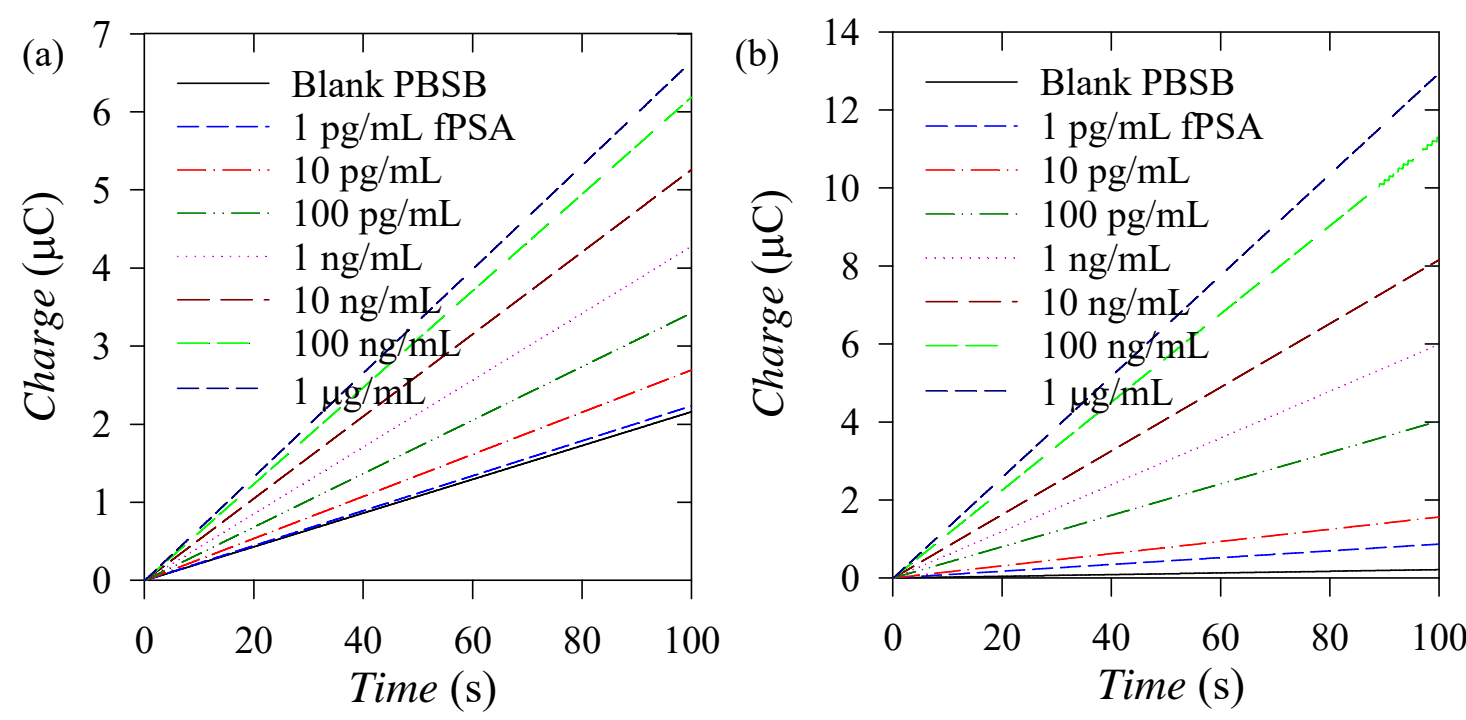

Figure S6. Chronocoulograms obtained (a) at $0.1 \mathrm{~V}$ without incubation and (b) $0.0 \mathrm{~V}$ after $30 \mathrm{~min}$ incubation at $37^{\circ} \mathrm{C}$ in tris buffer containing $0.1 \mathrm{mM} \mathrm{Fc}, 0.1 \mathrm{mM}$ peptide-AN, and $5 \mathrm{mM}$ glucose for the simultaneous detection of tPSA and fPSA (Scheme 1) in PBSB containing various concentrations of fPSA and zero cPSA. 

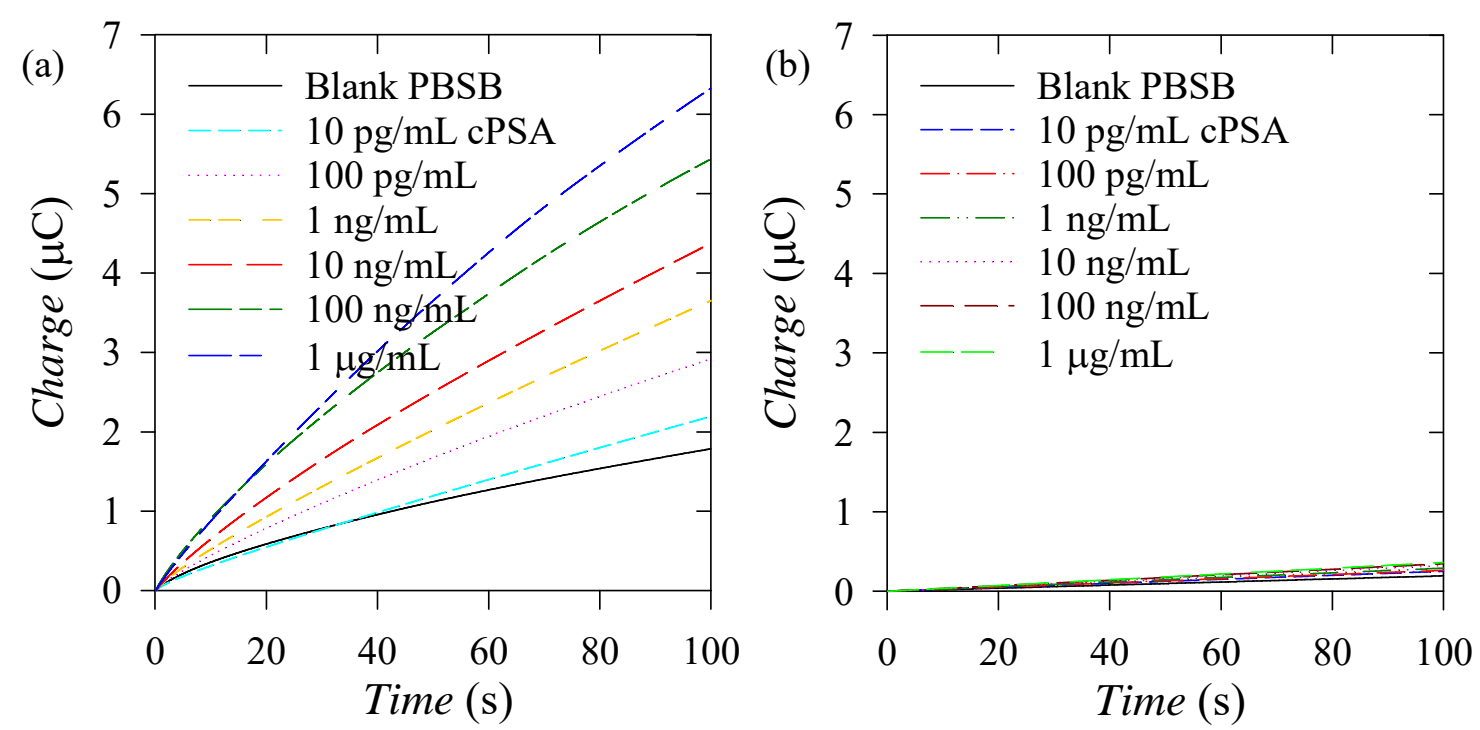

Figure S7. Chronocoulograms obtained (a) at $0.1 \mathrm{~V}$ without incubation and (b) $0.0 \mathrm{~V}$ after $30 \mathrm{~min}$ incubation at $37^{\circ} \mathrm{C}$ in tris buffer containing $0.1 \mathrm{mM} \mathrm{Fc}, 0.1 \mathrm{mM}$ peptide-AN, and $5 \mathrm{mM}$ glucose for the simultaneous detection of tPSA and PPSA (Scheme 1) in PBSB containing zero fPSA and various concentrations of cPSA. 

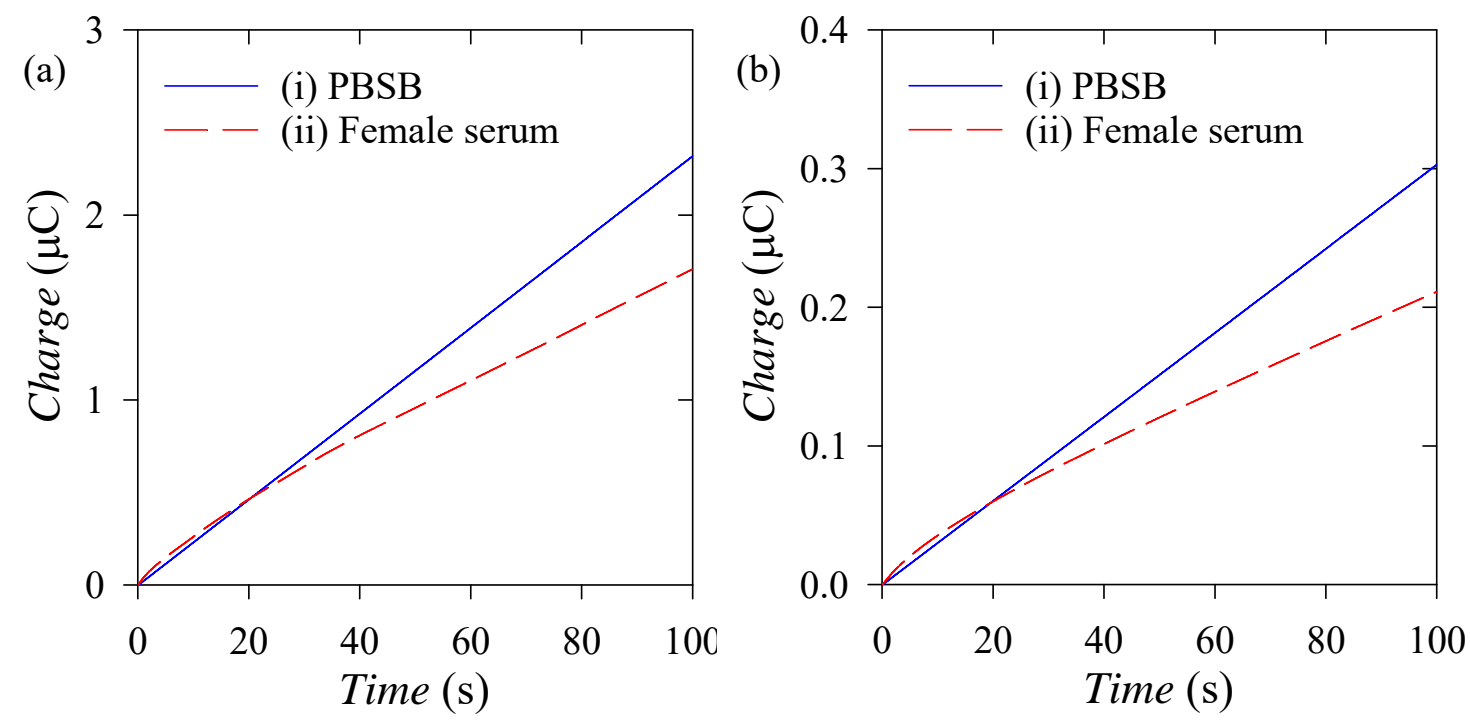

Figure S8. Chronocoulograms obtained (a) at $0.1 \mathrm{~V}$ without incubation and (b) $0.0 \mathrm{~V}$ after 30 min incubation at $37^{\circ} \mathrm{C}$ in tris buffer containing $0.1 \mathrm{mM} \mathrm{Fc}, 0.1 \mathrm{mM}$ peptide-AN, and $5 \mathrm{mM}$ glucose for the simultaneous detection of tPSA and fPSA (Scheme 1) in (i) PBSB and (ii) female serum containing no added tPSA and PPSA.

The two chronocoulograms obtained using the PBSB containing zero concentrations of fPSA and cPSA were similar to the two corresponding chronocoulograms obtained using female serum since the PSA concentration in healthy female human serum is very low. ${ }^{\mathrm{S} 2}$ 

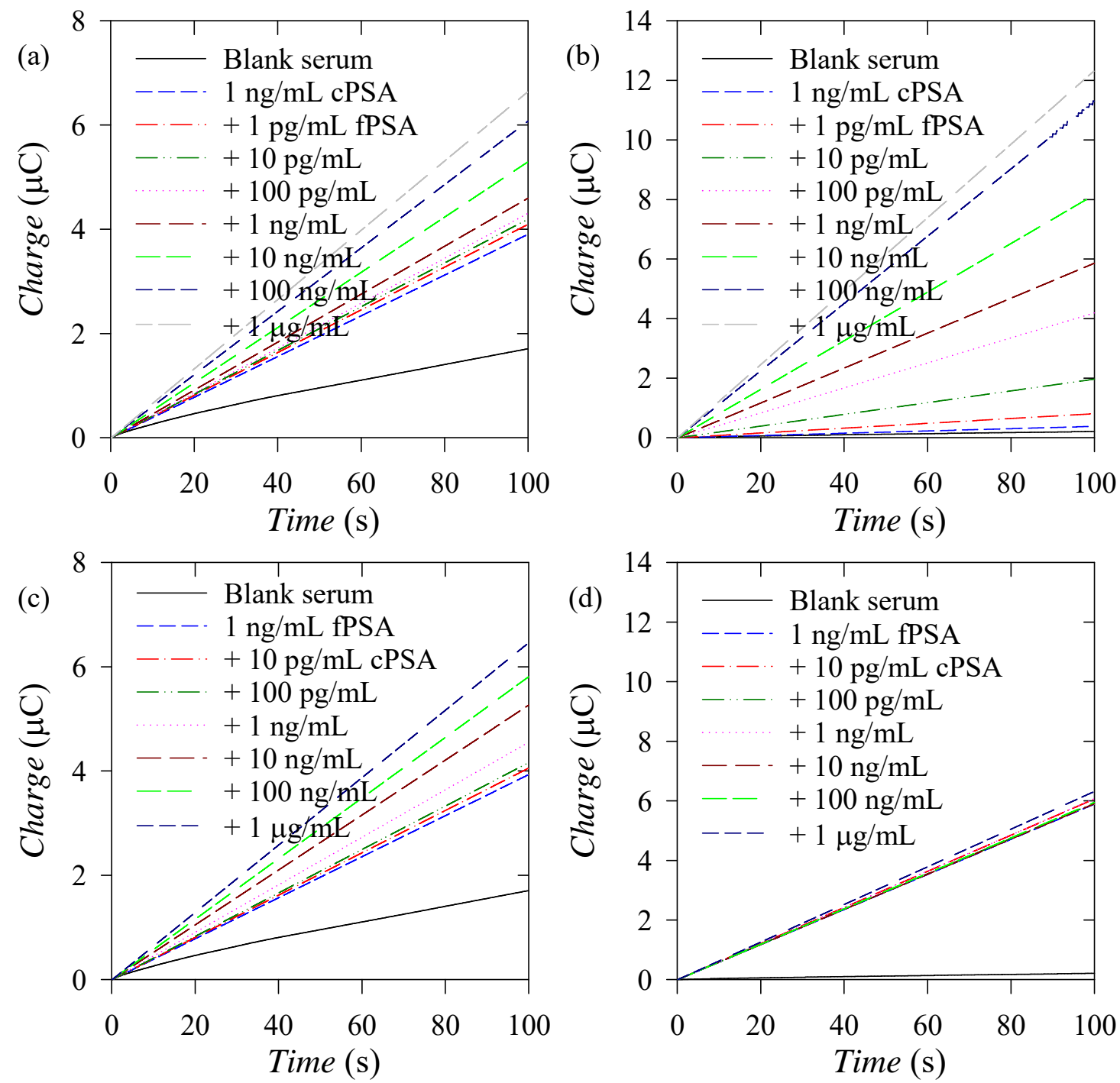

Figure S9. Chronocoulograms obtained (a, c) at $0.1 \mathrm{~V}$ without incubation and (b, d) 0.0 $\mathrm{V}$ after $30 \mathrm{~min}$ incubation at $37^{\circ} \mathrm{C}$ in tris buffer containing $0.1 \mathrm{mM} \mathrm{Fc}, 0.1 \mathrm{mM}$ peptide$\mathrm{AN}$, and $5 \mathrm{mM}$ glucose for the simultaneous detection of tPSA and PPSA (Scheme 1) in female serum $(a, b)$ containing various concentrations of fPSA and $1 \mathrm{ng} / \mathrm{mL}$ cPSA and (c, d) containing $1 \mathrm{ng} / \mathrm{mL}$ fPSA and various concentrations of cPSA. 


\begin{tabular}{|c|c|c|c|c|c|c|}
\hline $\begin{array}{c}\text { Sample } \\
\text { No. }\end{array}$ & $\begin{array}{c}\text { tPSA } \\
\text { Concentration } \\
(n g / m L)\end{array}$ & $\%$ fPSA & $\begin{array}{l}\text { Biopsy } \\
\text { needs* }\end{array}$ & $\begin{array}{l}\text { Measured } \\
\text { tPSA } \\
\text { Concentration }(\mathrm{ng} / \mathrm{mL})\end{array}$ & $\begin{array}{c}\text { Calculated } \\
\% \text { fPSA }\end{array}$ & $\begin{array}{l}\text { Calculated } \\
\text { Biopsy } \\
\text { needs* }\end{array}$ \\
\hline 1 & 1.5 & 26 & & 1.0 & 60 & \\
\hline 2 & 5.0 & 13 & & 5.6 & 9.6 & 0 \\
\hline 3 & 11 & 8.0 & 0 & 8.5 & 11 & \\
\hline 4 & 2.5 & 12 & & 1.6 & 35 & \\
\hline 5 & 2.0 & 28 & & 1.3 & 37 & \\
\hline 6 & 31 & 27 & 0 & 32 & 23 & 0 \\
\hline 7 & 8.7 & 22 & & 6.2 & 19 & \\
\hline 8 & 4.4 & 20 & & 7.1 & 8.9 & 0 \\
\hline 9 & 26 & 27 & 0 & 21 & 39 & 0 \\
\hline 10 & 9.7 & 21 & & 8.2 & 44 & \\
\hline 11 & 9.0 & 14 & & 11 & 8.9 & 0 \\
\hline 12 & 7.7 & 16 & & 5.3 & 42 & \\
\hline 13 & 0.040 & 25 & & 0.10 & 30 & \\
\hline 14 & 5.20 & 5.4 & 0 & 4.1 & 8.9 & 0 \\
\hline 15 & 3.2 & 11 & & 4.8 & 5.4 & 0 \\
\hline 16 & 6.6 & 6.7 & 0 & 5.5 & 10 & 0 \\
\hline 17 & 13 & 7.3 & 0 & 9.0 & 9.1 & 0 \\
\hline 18 & 4.7 & 34 & & 4.0 & 63 & \\
\hline 19 & 1.8 & 35 & & 2.0 & 26 & \\
\hline 20 & 0.29 & 35 & & 0.10 & 150 & \\
\hline
\end{tabular}

$\left({ }^{*}\right.$ When the tPSA concentration in the serum is $4-10 \mathrm{ng} / \mathrm{mL}$, biopsy is performed when \%fPSA is less than 10 percent. When tPSA concentration is above $10 \mathrm{ng} / \mathrm{mL}$, the prostate biopsy is recommended.)

Table S1. Comparison of the concentration of tPSA concentration, the $\%$ ratio of fPSAto-tPSA, and the biopsy needs ${ }^{23}$ measured by using the immunosensor and a commercial instrument for 20 clinical serum samples. 


\section{References}

(S1) Yoon, H.; Blaber, S. I.; Evans, D. M.; Trim, J.; Juliano, M. A.; Scarisbrick, I. A.; Blaber, M. Activation profiles of human kallikrein-related peptidases by matrix metalloproteinases. Protein Sci. 2008, 17, 1998-2007.

(S2) Borchert, G. H.; Giai, M.; Diamandis, E. P. Elevated levels of prostate-specific antigen in serum of women with fibroadenomas and breast cysts. J. Natl. Cancer Inst. 1997, 89, 587-588. 